\title{
Retronasal Olfaction Test Methods: A Systematic Review
}

\author{
Hüseyin Özay, Aslı Çakır, Mustafa Cenk Ecevit
}

Department of Otorhinolaryngology, Dokuz Eylül University School of Medicine, İzmir, Turkey

Background: This report produces a bibliographic study of psychophysical tests proposed clinical assessments of retronasal olfaction.

Aims: We review how these tests can be utilized and discuss their methodological properties.

Study Design: Systematic review.

Methods: We undertook a systematic literature review investigating the retronasal olfaction test methods. PubMed, the free online MEDLINE database on biomedical sciences, was searched for the period from 1984 to 2015 using the following relevant key phrases: "retronasal olfaction", "orthonasal olfaction", "olfaction disorders", and "olfaction test". For each of the selected titles cited in this study, the full manuscript was read and analyzed by each of the three authors of this paper independently before collaborative discussion for summation and analytical reporting. Two reviewers independently read the abstracts and full texts and categorised them into one of three subgroups as follow, suitable, not-suitable, and unsure. Then they cross-checked the results, and a third reviewer decided assigned the group "unsure" to either the suitable group or the not-suitable group. Fifty eight studies revealed as suitable for review by two authors whereas 13 found not suitable for review. The total amount of 60 uncertain (unsure) or differently categorized articles were further examined by the third author which resulted in 41 approvals and 19 rejections. Hence 99 approved articles passed the next step. Exclusion criteria were reviews, case reports, animal studies, and the articles of which methodology was a lack of olfaction tests. By this way excluded 69 papers, and finally, 30 original human research articles were taken as the data.

Results: The study found that the three most widely used and accepted retronasal olfaction test methods are the retronasal olfaction test, the candy smell test and odorant presentation containers. All of the three psychophysical retronasal olfaction tests were combined with orthonasal tests in clinical use to examine and understand the smell function of the patient completely. There were two limitations concerning testing: "the lack concentrations and doses of test materials" and "performing measurements within the supra-threshold zone".

Conclusion: The appropriate test agents and optimal concentrations for the retronasal olfaction tests remain unclear and emerge as limitations of the retronasal olfaction test technique. The first step to overcoming these limitations will probably require identification of retronasal olfaction thresholds. Once these are determined, the concept of retronasal olfaction and its testing methods may be thoroughly reviewed.

Keywords: Olfaction disorders, olfaction test, orthonasal olfaction, retronasal olfaction, systematic review

\section{RATIONALE}

\section{Olfaction: How do We Smell?}

Olfaction is a major component of human chemosensation that integrates with the other senses and plays a critical role in environmental perception (1). Its contributions to cautionary behavior, such as perceiving spoiled food, fire smoke or a gas leak, make olfaction a vital sensation. Its interrelation with the sense of taste contributes to our ability to enjoy the savor of food (2).

The human olfactory system can recognize approximately one trillion olfactory stimuli (3). Evolutionarily, four vertical anatomical components (two medial constituents of the olfactory clefts and two lateral constituents of the ethmoid labyrinths) comprise the olfactory nose, and the olfactory mucosa covers only the surface of the roof of the olfactory clefts. With evolutionary advances in humans and higher primates, the importance of olfaction has decreased (4).

Olfaction is initiated when odor particles in the nasal air flow reach the olfactory epithelium and interact with odorant binding proteins, and the sensation is finalized with the conclusion of cortical processing. Thalamic connections underlie the conscious portion of olfaction. The entorhinal cortex and amygdala, which are sections of the limbic system, constitute the emotional component of the sensation (5).

Odorants mainly use two different routes for travel toward the olfactory epithelium, located orthonasally and retronasally. Along the orthonasal route, solutes dissolved in the air pass through the nostrils via the turbinates and eventually reach the olfactory epithelium. The retronasal route, however, requires a retrograde direction starting from the oral cavity, continuing through the

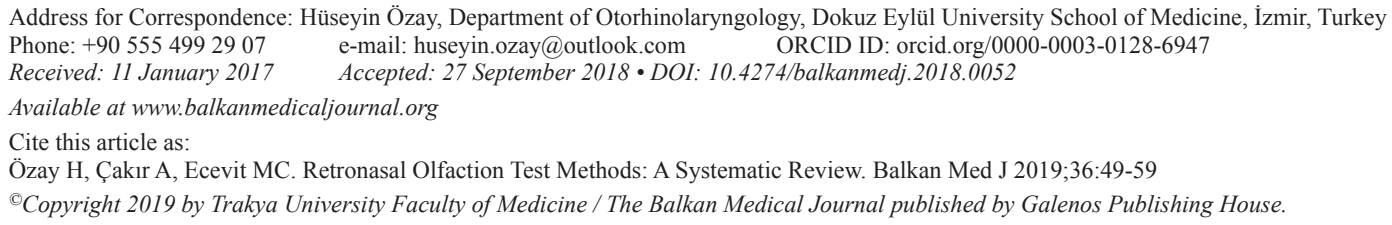


nasopharynx and choana and ending at the olfactory mucosa (6). According to Rozin, whereas orthonasal olfaction integrates with the external world, retronasal olfaction reflects the inner world (7). As the orthonasal route serves as the primary source of olfaction, the retronasal route also attracts attention, especially for ensuring the integrity of taste perception while eating. Since anosmic people experience alterations in eating habits and suffer from a decrease in taste bud activity, retronasal olfaction may play a critical role in flavor perception (8).

\section{Measuring Olfaction}

The olfaction test battery consists of electrophysiological and psychophysical tests and measurements. Electrophysiological tests measure cortical neural responses to an odor stimulus and olfaction detection thresholds via electroencephalography. Psychophysical tests, on the other hand, provide qualitative information about olfaction rather than the objective results obtained from electrophysiological recordings and thus are only employed for clinical symptom assesment (9).

Psychophysical tests are used to assess olfactory identification (OI), olfactory discrimination (OD), and the olfactory threshold (OT). Among these, the OT refers to the lowest concentration of odor perceived by the patient. However, OD and OI are assigned within supra-threshold values (10).

Numerous validated orthonasal tests have been reported in the contemporary literature. The University of Pennsylvania Smell Identification Test (10), the Sniffin' Sticks (11), and the Connecticut Chemosensory Clinical Research Center Test (12) are among the most popular.

\section{What is the Difference Between Orthonasal and Retronasal Olfaction and Why is it Important?}

Electrophysiological, psychophysical, and radiological studies point to the differences regarding perception and processing between the retronasal and orthonasal pathways. The disgusting aroma of a piece of stinky cheese can be sensed as a very pleasant flavor. Rombaux et al. (13) highlighted the contributions of air flow variations to this inconsistency and pointed to the importance of nasal air flow. Using functional magnetic resonance imaging, these two routes were shown to activate distinct regions in the cerebrum. Retronasal stimulation was demonstrated to share the same representation area as the oral cavity.

Declines in olfaction and taste sensation act concomitantly. In most cases, taste sensation problems even precede olfaction-related complaints. Therefore, retronasal olfaction tests were used by many authors to evaluate the olfactory component of sensory perception (7). Despite the fact that olfactory disorders are not rare situations and can worsen with both orthonasal and retronasal olfaction and with taste, improvements in retronasal testing lag far behind orthonasal test methods. There is not only a lack of validation of these tests but also a lack of knowledge about whether OI requires supra-threshold measurements (14).

\section{OBJECTIVE}

The current systematic review focuses on the limited available literature described above, with the purpose of examining what is known about psychophysical testing related to retronasal olfaction, as well as reviewing how such testing is employed and discussing the current methodology and its validity.

\section{MATERIALS AND METHODS}

\section{Search Strategy}

We searched PubMed, the free online search engine accessing the MEDLINE database of typically peer-reviewed literature in the biomedical sciences, for the period from 1984 to 2015, using four relevant key phrases: "retronasal olfaction," "orthonasal olfaction," "olfaction disorders," and "olfaction test."

\section{Inclusion and Exclusion Criteria}

\section{Subject investigated and inclusion criteria}

Our search strategy returned 131 abstracts. The titles and abstracts of all 131 entries were analyzed by two authors of this review, independently of each other, with a scoring system of suitable/ unsuitable/unsure as to whether the articles required further reading and review. Abstracts were considered "unsuitable" or "unsure" if they described a case report or experimental research conducted on animals or if methodology involving olfaction testingwas lacking. According to this scoring system, 58 and 13 entries were deemed suitable and unsuitable, respectively. For the 60 entries scored as "unsure," a consultation with the third author of this study was performed. The consultation revealed 41 suitable and 19 unsuitable abstracts.

\section{Quality evaluation, prevention of bias, and data exctraction}

According to the bias risk assessment tool recommended by the Cochrane Review Handbook 5.1 (15), two reviewers independently read the abstracts and full texts and categorized them into one of three subgroups as follows: suitable, unsuitable, and unsure. Then they cross-checked the results, and a third reviewer assigned articles designated as "unsure" to either the suitable group or the unsuitable group.

\section{Additional exclusion criteria}

Once 99 suitable abstracts were obtained, their full texts were read by the three authors of this study, independently of each other. For these 99 full texts, the following additional criteria were established to exclude articles from further consideration: the article was a review, case report, or study involving animals, or the article included no methodology involving olfaction testing. The authors agreed to exclude 69 of the 99 full texts according to these additional exclusion criteria. Finally, we obtained 30 full texts of original clinical studies. Figure 1 illustrates a flow diagram of the article selection process.

\section{Intervention and Outcome Measures}

The final dataset was searched for psychophysical retronasal tests. Patients' demographic characteristics; technical and methodological properties of orthonasal and retronasal olfaction tests; and other retronasal-test-related parameters, such as the number of stimulants, the application procedure, subgroup differences, and statistical analyses used to perform validity measurements, were entered and evaluated. 


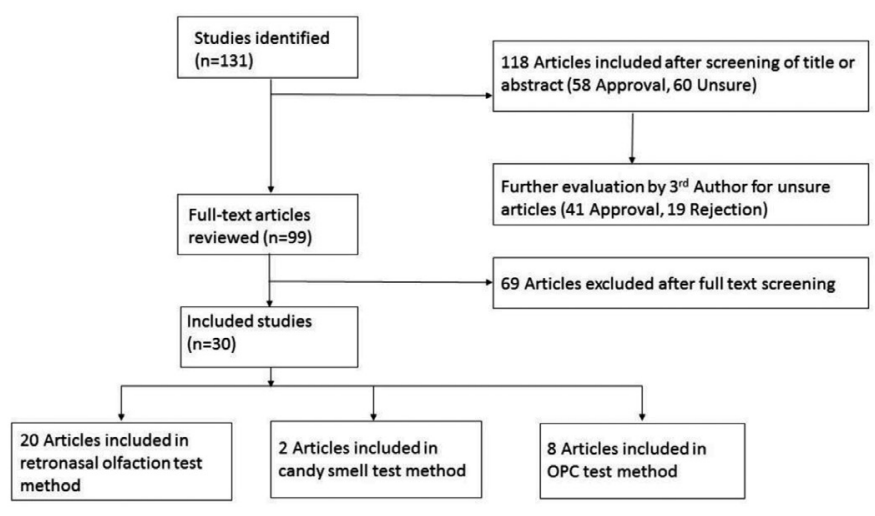

FIG. 1. Flow diagram illustrating the study selection process. OPC: Odorant Presentation Containers

\section{Data analysis}

Outcome measures were recorded in a personal computer. Results were analyzed by using a Microsoft Excel 2010 worksheet (Microsoft, USA) for Windows 7.0 (Microsoft, USA) and are presented in the Results section.

\section{RESULTS}

\section{Risk of Bias within Studies}

According to the bias risk assessment tool recommended by the Cochrane Review Handbook 5.1 (15), all of the abstracts and full-text data were reviewed by the authors of the current study, independently from each other. Our exclision criteria further prevented the risk of bias, because we excluded all studies that did not include a detailed explanation of the olfaction testing method, case reports, animal or experimanteal work, and reviews.

Results of Individual Studies and Synthesis of Results

The three most widely used and accepted retronasal olfaction test methods uncovered in this systematic review are listed here and detailed below.

- Retronasal Olfaction Test (ROT)

- Candy Smell Test (CST)

- Odorant Presentation Containers (OPC)

\section{Retronasal olfaction test technique}

First introduced by Heilmann et al. (16) in 2002, the ROT is a relatively simple test procedure which assesses retronasal olfaction using an oral stimulant. Taste stimulant powders weighing approximately $50 \mathrm{mg}$ are available in squeezable plastic vials and applied through a 6 -cm-long spout placed on the middle of the tongue. Individuals are requested to choose one of four different test agents at each session. Intersession periods last for 1 minute, during which participants are asked to rinse their mouths with tap water. Thirty different food or condiment powders recognizable by $70 \%$ of the normosmic population, such as bread, milk, strawberry, ginger, grapefruit, vanilla, onions, oranges, cocoa, celery, coffee, smoked ham, cloves, garlic, white grape, mushrooms, red pepper, lime, raspberry, curry, and cinnamon, were presented to 230 volunteers, both healthy and with olfaction disorders. Substances not recognizable to at least $70 \%$ of the normosmic population, such as anise, cumin, bacon, mustard, blueberry, almond, cherry, and coconut, were not employed. Additionally, lemon and pepper, which can be identified by more than $80 \%$ of even hyposmic and anosmic patients as a result of trigeminal stimulation, were also not studied. Validation analyses were performed using Sniffin' sticks TDI score. Results of the comparison between orthonasal and retronasal applications and subgroup differences in retronasal application between normosmic, hyposmic, and anosmic volunteers were statistically significant. Heilmann et al. (16) offered oral flavor powders as useful stimulants and recommended the ROT as an appropriate diagnostic tool.

A year after the study by Heilmann et al. (16), Landis et al. (17) reported using 10 different odorants in a study designed to examine orthonasal and retronasal olfaction in patients with a diagnosis of nasal polyposis. For orthonasal olfaction testing, subjecs were asked to identify 10 substances (lemon, banana, garlic, cinnamon, orange, licorice, apple, mint, pineapple, and coffee), and the Sniffin' Sticks test battery was used for retronasal olfaction testing. Three substance (rose, turpentine, and leather) involved in orthonasal olfaction and two (fish and cloves) with retronasal olfaction were not included. The application procedure was similar to that of the Heilmann et al. (16) study, and results indicated that retronasal olfaction functions better than orthonasal olfaction in patients with a diagnosis of nasal polyposis. This is most probably related to mechanical obstruction of the anterior portion of the olfactory groove (17).

Retronasal olfaction testing continued to inspire several researchers interested in this issue. Among these researchers, Konstantinidis et al. (18) employed similar testing methods but used different substances, such as oranges, coffee, garlic, cloves, cocoa, celery, strawberries, onion, muscadine grapes, ham, mushrooms, and cinnamon, to understand the possible effects of adenoid hypertrophy $(\mathrm{AH})$ on olfaction and gustation in a pediatric population. As a result of comparing orthonasal and retronasal olfaction between the pre- and postoperative course, adenoidectomy was suggested to have positive effects on retronasal olfaction.

In a study by Pfaar et al. (19) to demonstrate the impact of mechanical obstruction of the olfactory groove on orthonasal and retronasal olfaction, 33 healthy volunteers were tested after having sponge strips placed into the nares on the targeted area, the olfactory epithelium. This research found a significant decrease in orthonasal olfaction compared with retronasal olfaction, with the implication of possible relevance of an orthonasal olfaction defect associated with nasal polyposis.

Subsequently, Rombaux et al. (20) employed the testing technique of Heilmann et al. (16) on a single patient and a sample of healthy participants consisting of four equally sized diagnosis subgroups: nasal polyposis (NP), postinfectious (PI) olfaction deficiency, posttraumatic olfaction decrement, and normosmia. The ROT was adequately capable of appealing the significantly higher retronasal olfaction scores in the NP group.

In 2007, Leon et al. (21) reported a case-control study involving 36 patients who had undergone total laryngectomy (TL) versus 36 smoking control subjects. Orthonasal measurements were 
performed using $\mathrm{CCCRC}$, and retronasal evaluation was achieved using the method of Heilmann et al. (16). Among 20 variables, another type included grape and chicken bouillon (instead of muscadine grapes and smoked ham) and seriatim, in consideration of incompatible sociocultural taste differences and behavior. It was concluded that both routes of olfaction were hypo-functional in the TL group (21).

Croy et al. (22) carried out a multi-center research study comprising seven different countries and employing the methods described above with some minor alterations. First, 24 of 36 taste substances were used, and second, 20 substances which could be identified by more than $50 \%$ of normosmic subjects and by fewer than $50 \%$ of anosmic participants were assigned. The results of the research added a significant finding to the literature showing an age-dependent decrease in orthonasal olfaction, whereas retronasal olfaction was independent of age. Croy et al. (22) asserted that the ROT is not suitable for daily clinical use but should be particularly beneficial in the case of a taste disorder accompanying olfaction deficiency. Studies investigating the ROT are summarized in Table 1 (16-36).

\section{Candy smell test technique}

Renner et al. (37) sought to develop a practical retronasal olfaction testing method that could easily be used in both adult and pediatric populations; hence, the CST was developed. This test makes use of 23 different candies, each including a unique flavor: cola, banana, coffee, lemon, passion fruit, blackberry, cinnamon, orange, pineapple, peach, pear, anise,

TABLE 1. Summary of studies investigating the retronasal olfaction test

\begin{tabular}{|c|c|c|c|c|}
\hline Authors & Aim & Study group & Main finding & Main conclusion \\
\hline $\begin{array}{l}\text { Heilmann } \\
\text { et al. }{ }^{16}\end{array}$ & $\begin{array}{l}\text { To develop a test kit for the } \\
\text { simple assesment of retronasal } \\
\text { olfactory function }\end{array}$ & $\begin{array}{l}230 \text { individuals with } \\
\text { normosmia }(n=120) \text {, } \\
\text { hyposmia }(n=37) \text {, and } \\
\text { anosmia }(n=73)\end{array}$ & $\begin{array}{l}\text { Orthonasal and retronasal identification } \\
\text { of odors was found to correlate. } \\
\text { Retronasal testing allowed for the } \\
\text { discrimination between normosmia, } \\
\text { hyposmia and anosmia }\end{array}$ & $\begin{array}{l}\text { The assessment of retronasal } \\
\text { olfactory function is possible } \\
\text { using oral stimulus presentation }\end{array}$ \\
\hline $\begin{array}{l}\text { Konstantinidis } \\
\text { et al. }{ }^{18}\end{array}$ & $\begin{array}{l}\text { To assess the ability to smell and } \\
\text { appreciate food in children with } \\
\text { adenoid hypertrophy pre and } \\
\text { post-adenoidectomy }\end{array}$ & $\begin{array}{l}35 \text { children with adenoid } \\
\text { hypertrophy admitted } \\
\text { for adenoidectomy, } 30 \\
\text { healthy children }\end{array}$ & $\begin{array}{l}\text { The difference in retronasal olfaction } \\
\text { between groups was significantly higher } \\
\text { in comparison with the difference in } \\
\text { orthonasal odor identification. There is } \\
\text { a strong correlation between adenoid } \\
\text { hypertrophy grade and retronasal testing } \\
\text { results, but not with the orthonasal } \\
\text { results }\end{array}$ & $\begin{array}{l}\text { Children with hypertrophic } \\
\text { adenoids have a reduced ability } \\
\text { to identify odors and enjoy foods. } \\
\text { In addition retronasal olfactory } \\
\text { function in these children seems } \\
\text { to be more affected, indicating a } \\
\text { significant }\end{array}$ \\
\hline Landis et al. ${ }^{23}$ & $\begin{array}{l}\text { To investigate differences } \\
\text { between orthonasal and } \\
\text { retronasal olfaction in patients } \\
\text { with loss of the sense of smell } \\
\text { without taste complaints }\end{array}$ & $\begin{array}{l}\text { A series of } 18 \text { patients } \\
\text { who had olfactory loss } \\
\text { due to various reasons } \\
\text { but no "taste" complaints }\end{array}$ & $\begin{array}{l}\text { Psychophysical testing revealed } \\
\text { retronasal olfaction to be normal or } \\
\text { slightly altered, whereas orthonasal } \\
\text { olfaction was either absent or severely } \\
\text { compromised }\end{array}$ & $\begin{array}{l}\text { These clinical observations, } \\
\text { together wih the psychophysical } \\
\text { and electrophysiological findings, } \\
\text { suggest that orthonasal and } \\
\text { retronasal olfaction might be } \\
\text { processed differently }\end{array}$ \\
\hline Pfaar et al. ${ }^{19}$ & $\begin{array}{l}\text { To investigate whether a } \\
\text { mechanical obstruction of the } \\
\text { anterior olfactory cleft would } \\
\text { produce differential effects } \\
\text { on orthonasal and retronasal } \\
\text { olfactory functions }\end{array}$ & 33 healthy subjects & $\begin{array}{l}\text { The results indicated that orthonasal } \\
(\mathrm{p}=0.04) \text { but not retronasal }(\mathrm{p}=0.15) \\
\text { olfactory identification ability was } \\
\text { lower when the olfactory cleft was } \\
\text { blocked }\end{array}$ & $\begin{array}{l}\text { Differences between orthonasal } \\
\text { and retronasal olfactory functions, } \\
\text { as observed in nasal polyposis } \\
\text { patients, are at least to some } \\
\text { degree due to mechanical } \\
\text { obstruction of the anterior portion } \\
\text { of the olfactory cleft }\end{array}$ \\
\hline $\begin{array}{l}\text { Rombaux et } \\
\text { al. }^{20}\end{array}$ & $\begin{array}{l}\text { To evaluate olfactory function } \\
\text { with orthonasal and retronasal } \\
\text { testing in patients with } \\
\text { posttraumatic olfactory loss } \\
\text { and to investigate the relation } \\
\text { between residual olfactory } \\
\text { function and olfactory bulb } \\
\text { volume }\end{array}$ & $\begin{array}{l}25 \text { patients with } \\
\text { posttraumatic olfactory } \\
\text { loss }\end{array}$ & $\begin{array}{l}\text { The demonstration of a correlation } \\
\text { between olfactory function and } \\
\text { olfactory bulb volume, which was } \\
\text { more pronounced for retronasal than } \\
\text { for orthonasal olfactory function; } \\
\text { retronasal olfactory function was most } \\
\text { affected in the patients with the most } \\
\text { extensive cerebral damage and was least } \\
\text { compromised in patients without such } \\
\text { damage }\end{array}$ & $\begin{array}{l}\text { Olfactory bulb volume is an } \\
\text { indicator of olfactory function but, } \\
\text { interestingly, in this study, it is } \\
\text { largely determined by retronasal } \\
\text { olfactory sensitivity }\end{array}$ \\
\hline $\begin{array}{l}\text { Rombaux et } \\
\text { al. }{ }^{24}\end{array}$ & $\begin{array}{l}\text { To investigate whether } \\
\text { differences in olfactory function } \\
\text { between healthy individuals and } \\
\text { patients with olfactory loss could } \\
\text { be detected by various diagnostic } \\
\text { tests }\end{array}$ & $\begin{array}{l}\text { Eleven healthy individuals } \\
\text { with normal olfactory } \\
\text { function and } 11 \text { patients } \\
\text { with nasal polyposis, } \\
11 \text { with posttraumatic } \\
\text { olfactory loss, and } 11 \text { with } \\
\text { postinfectious olfactory } \\
\text { loss }\end{array}$ & $\begin{array}{l}\text { Retronasal scores were higher in } \\
\text { nasal polyposis patients compared } \\
\text { with posttraumatic olfactory loss and } \\
\text { postinfectious olfactory loss patients }\end{array}$ & $\begin{array}{l}\text { This finding suggests that } \\
\text { these diagnostic tools provide } \\
\text { information in terms of the clinical } \\
\text { assessment of olfactory function }\end{array}$ \\
\hline
\end{tabular}


TABLE 1. Continued

\begin{tabular}{ll}
\hline Authors & Aim \\
\hline Leon et al. ${ }^{21}$ & $\begin{array}{l}\text { To characterize orthonasal and } \\
\text { retronasal olfactory ability in } \\
\text { patients who have had a total } \\
\text { laryngectomy }\end{array}$ \\
& \\
Rombaux et & $\begin{array}{l}\text { To evaluate the likelihood of } \\
\text { al. }{ }^{25}\end{array}$ \\
& $\begin{array}{l}\text { pocording olfactory event-related } \\
\text { olfactory dysfunction and to } \\
\text { correlate the electrophysiological } \\
\text { responses to orthonasal and } \\
\text { retronasal olfactory testing }\end{array}$ \\
& $\begin{array}{l}\text { To assess the usefulness and } \\
\text { feasibility of these diagnostic } \\
\text { tools in the rhinology clinic and } \\
\text { to correlate these results to the } \\
\text { olfactory disorder aetiology } \\
\text { al. }{ }^{26}\end{array}$ \\
\end{tabular}

Landis et al. ${ }^{27}$ To investigate retronasal versus orthonasal olfactory function in Parkinson's disease
Fleiner et al. ${ }^{28}$ To evaluate the olfactory function and gustatory function in patients with multiple sclerosis
Roudnitzky et al. ${ }^{29}$
Aim of this study was to better understand interactions between synchronous tactile (texture) and olfactory (odor) sensations, using a psychophysical and an electrophysiological approach
16 multiple sclerosis patients, 16 healthy controls
Eighteen subjects (11 women, 7 men, mean age 24 years)

60 patients with postinfectious $(\mathrm{n}=28)$ and posttraumatic olfactory loss $(\mathrm{n}=32)$
Main finding

Evaluation of retronasal olfactory ability resulted in a mean score of 11.0 (maximum score, 20) for the total laryngectomy group vs. 14.3 for the control group $(\mathrm{p}<0.001)$ 3.5 years) and 36 agesex-, and smoking istory-matched controls

Causes of olfactory dysfunction included oss $(n=15)$, head trauma $\mathrm{n}=15)$, and mixed drug induced) $(\mathrm{n}=9)$

47 chronic rhinosinusitis and without postinfection olfactory event, 63 posttraumatic factory event, 8 10 toxic and/or postmedication olfactory disease (Neuro.) 24 idiopathicolfactory dysfunction (Idiop.)

45 Parkinson's disease patients

The mean correct orthonasal identification score for Parkinson's disease patients was $56 \%$ and the mean retronasal identification rate was $60 \%$. There was no significant difference between ortho- and retronasal odor identification

Eight of 16 multiple sclerosis patients $(50 \%)$ displayed hyposmia; the identification subtest significantly was restricted. Four of 16 multiple sclerosis patients $(25 \%)$ had limited retronasal olfactory function with a Taste Powder score of $4.5 \pm 1.29$

For the psychophysical data, the presence of an oral stimulus increased odor intensity, irrespective of odor presentation route. For the electrophysiological data, both early and late chemosensory event-related potentials were affected by odor conditions, texture conditions, and their respective interaction

There was a correlation between both orthonasal and retronasal olfactory testing and the initial measurement of the total olfactory bulb volume
Main conclusion

Laryngectomy is associated with measurable decreases in olfactory fuction that are also subjectively perceived

Combining psychophysical testing and olfactory event-related potentials recording may allow the clinician to perform an accurate diagnosis of olfactory dysfunction

Psychophysical olfactory testing is a useful method to assess olfactory function in patients with olfactory loss and may help us to obtain a semi-objective and a basal evaluation of the olfactory performances

Retronasal and orthonasal olfactory function are severely impaired in Parkinson's disease patients, and this impairment is of similar magnitude for both functions

This study confirms the incidence of olfactory disorder in multiple sclerosis patients that has been reported in the literature

(1) perceptual interactions occurred between food texture and odor, with cross-modal interactions being found for both orthonasal and retronasal odor administration

(2) these interactions between texture and odor occur at both primary-sensory and cognitive evaluative levels of stimulus processing

Olfactory bulb volume seems to be a predictor of olfactory recovery in patients with postinfectious and posttraumatic olfactory loss recovery in postinfectious and
redictor of olfactory posttraumatic olfactory loss 
TABLE 1. Continued

\begin{tabular}{|c|c|c|c|c|}
\hline Authors & Aim & Study group & Main finding & Main conclusion \\
\hline Croy et al. ${ }^{22}$ & $\begin{array}{l}\text { To compare retronasal function } \\
\text { across different cultures and to } \\
\text { develop a test that is applicable } \\
\text { across cultures }\end{array}$ & $\begin{array}{l}518 \text { participants of } \\
\text { seven countries; } 292 \\
\text { of them were healthy } \\
(157 \mathrm{M}, 135 \mathrm{~W}) \text {, and } \\
226 \text { exhibited a smell } \\
\text { disorder }(111 \mathrm{M}, 115 \mathrm{~W}) . \\
16-94 \text { age range }\end{array}$ & $\begin{array}{l}\text { This test was well able to differentiate } \\
\text { between controls and patients in } \\
\text { different countries and showed a good } \\
\text { coherence with the orthonasal test } \\
(\mathrm{r}=0.80) \text { and a good retest-reliability } \\
(\mathrm{r}=0.76) \text {. An advantage of the retronasal } \\
\text { test is that is shows no age dependency } \\
\text { for our sample of middle-aged persons. } \\
\text { In contrast, orthonasal identification has } \\
\text { been shown to decrease with age }\end{array}$ & $\begin{array}{l}\text { This retronasal, clinical olfactory } \\
\text { test is easy to understand and } \\
\text { rapidly performed within }<20 \\
\text { min which is, therefore, good } \\
\text { for people with concentration } \\
\text { problems }\end{array}$ \\
\hline $\begin{array}{l}\text { Salihoğlu } \\
\text { et al. }{ }^{31}\end{array}$ & $\begin{array}{l}\text { To investigate the effect of } \\
\text { obstructive sleep apnea on } \\
\text { theparameters of olfactory } \\
\text { functions for orthonasal } \\
\text { olfaction, retronasal olfactory } \\
\text { testing, and olfactory bulb } \\
\text { volumes }\end{array}$ & $\begin{array}{l}26 \text { control group, } 29 \text { mild } \\
\text { to moderate obstructive } \\
\text { sleep apnea group, } 23 \\
\text { severe obstructive sleep } \\
\text { apnea group }\end{array}$ & $\begin{array}{l}\text { Orthonasal olfaction was impaired } \\
\text { significantly in patients with obstructive } \\
\text { sleep apnea, but no significant } \\
\text { impairment was detected in retronasal } \\
\text { olfaction }\end{array}$ & $\begin{array}{l}\text { obstructive sleep apnea had } \\
\text { significant negative effects on } \\
\text { all orthonasal olfactory tasks, } \\
\text { especially on threshold and } \\
\text { discrimination. Volumetric } \\
\text { magnetic resonance imaging } \\
\text { also demonstrated volumetric } \\
\text { shrinkage of olfactory bulb } \\
\text { volumes }\end{array}$ \\
\hline Cayonu et al. ${ }^{32}$ & $\begin{array}{l}\text { To investigate the mass effect of } \\
\text { palatine tonsillar hypertrophy on } \\
\text { retronasal olfaction }\end{array}$ & $\begin{array}{l}\text { Grade } 1: 43 \\
\text { Grade 2: } 29 \\
\text { Grade 3: } 42 \\
\text { Grade 4: } 32\end{array}$ & $\begin{array}{l}\text { There was no difference between the } \\
\text { groups in terms of "Sniffin' Sticks" } \\
\text { subtests and TDI scores. It was } \\
\text { determined that the retronasal olfactory } \\
\text { scores of the participants with grade } 4 \\
\text { tonsil size were significantly lower than } \\
\text { the retronasal olfactory scores of the } \\
\text { participants with grade } 1 \text { tonsil size }\end{array}$ & $\begin{array}{l}\text { Grade } 4 \text { tonsillar hypertrophy has } \\
\text { significant negative effects on } \\
\text { the retronasal route of olfactory } \\
\text { sensing, when compared with } \\
\text { grade } 1 \text { tonsillar hypertrophy }\end{array}$ \\
\hline $\begin{array}{l}\text { Salihoglu } \\
\text { et al. }{ }^{33}\end{array}$ & $\begin{array}{l}\text { To perform a preliminary study } \\
\text { for the validation of "retronasal } \\
\text { olfactory testing" in the Turkish } \\
\text { population to find the best way to } \\
\text { evaluate smell and taste disorders } \\
\text { in Turkey }\end{array}$ & 330 volunteers & $\begin{array}{l}\text { There was a strong significant } \\
\text { correlation between the TDI scores } \\
\text { and retronasal olfactory test scores. } \\
\text { Retronasal olfactory testing allowed } \\
\text { for discriminating between normosmic, } \\
\text { hyposmic, and anosmic subjects. } \\
\text { Specifically, there was almost no } \\
\text { overlap between scores of anosmic and } \\
\text { normosmic subjects }\end{array}$ & $\begin{array}{l}\text { These results provide the basis } \\
\text { for routine clinical evaluation of } \\
\text { patients with olfactory disorders } \\
\text { using retronasal olfactory testing, } \\
\text { which is a simple and easy-to- } \\
\text { perform test of the retronasal } \\
\text { olfaction in our sample of the } \\
\text { Turkish population }\end{array}$ \\
\hline $\begin{array}{l}\text { Altundag } \\
\text { et al. }{ }^{35}\end{array}$ & $\begin{array}{l}\text { To evaluate the olfactory } \\
\text { abilities of subjects with chronic } \\
\text { halitosis evaluated using the } \\
\text { measurements of volatile sulfur } \\
\text { compounds }\end{array}$ & $\begin{array}{l}\text { Patient group: } 43 \\
\text { (halitosis) } \\
\text { Control group: } 34\end{array}$ & $\begin{array}{l}\text { The differences in odor threshold } \\
\text { scores were significant between the } \\
\text { groups, whereas no significant change } \\
\text { was detected between them in terms of } \\
\text { odor identification and discrimination } \\
\text { scores, despite the decreases in the } \\
\text { halitosis group when compared with the } \\
\text { control group. With regard to retronasal } \\
\text { olfaction, the groups did not differ }\end{array}$ & $\begin{array}{l}\text { The results suggest that the } \\
\text { chronic presence of volatile sulfur } \\
\text { compounds may have a negative } \\
\text { effect on olfactory function }\end{array}$ \\
\hline
\end{tabular}


TABLE 1. Continued

\begin{tabular}{|c|c|c|c|c|}
\hline Authors & Aim & Study group & Main finding & Main conclusion \\
\hline $\begin{array}{l}\text { Reychler } \\
\text { et al. }{ }^{36}\end{array}$ & $\begin{array}{l}\text { To assess and to compare the } \\
\text { effectiveness of three modalities } \\
\text { of corticosteroids administration } \\
\text { in patients with chronic } \\
\text { rhinosinusitis }\end{array}$ & $\begin{array}{l}\text { Thirty patients with } \\
\text { chronic rhinosinusitis } \\
\text { were randomized in three } \\
\text { groups depending on the } \\
\text { route of corticosteroids } \\
\text { administration: oral } \\
\text { route, nasal spray, sonic } \\
\text { nebulization }\end{array}$ & $\begin{array}{l}\text { In vitro differences in drug deposition } \\
\text { pattern between both intranasal } \\
\text { modalities were demonstrated. } \\
\text { Threshold discrimination identification } \\
\text { and repetitive negative thinking were } \\
\text { similar between three groups at baseline }\end{array}$ & $\begin{array}{l}\text { Effectiveness of sonic nebulized } \\
\text { and oral administration is } \\
\text { demonstrated on orthonasal } \\
\text { olfactory. The clinical benefit is } \\
\text { better than with nasal spray }\end{array}$ \\
\hline
\end{tabular}

sweet woodruff (coumarin-like aroma), gingerbread, kiwi, red currant, apple, nuts, vanilla, mandarin, strawberry, mint, and cherry. Five hundred milligrams of sorbitol is used as an inert supplement. The flavors are selected from the Sniffin' Sticks identifying test. With the nose clipped, the candy is placed on the middle of the tongue, and after sucking on the candy, individuals are presented a choice of one of four different test agents in each session. The main difference between the ROT and this test is the non-stop testing manner during chewing and swallowing of the CST. Each correct answer is scored one point. The cutoff point for anosmia is 13 . The test is validated according to the Sniffin' Sticks TDI scoring, and it possesses $83 \%$ specificity and 94\% sensitivity (38). Haxel et al. (38) tried the CST in a case-control study, validated it using the Sniffin' Sticks orthonasal test, and ranked it as an easy and reliable test method that can be performed for discriminating normosmic, hyposmic, and anosmic individuals in daily clinical practice. These studies are summarized in Table 2.

\section{Odorant presentation container technique}

Pierce and Halpern (39) performed pioneering research on finding ways to prevent agents in the oral cavity from reaching the olfactory epithelium. Their discoveries, reported in 1996, first described a procedure in which orthonasal and retronasal stimulation interacted with taste and thermal or mechanical senses while traveling to the olfactory mucosa. The authors developed odorant presentation containers (OPCs) and placed them in the mouth. OPCs were introduced in detail in their original research. Briefly, the specially manufactured OPC is composed of two telescoped cylinders, which provide isolation between the solid odorant in the inner cylinder and the oral tissue. The product also lacks any thermal, gustatory, and taste stimulants. Retronasal olfaction is achieved by OPCs during exhalation through the nose. Visual input is prohibited by asking participants to close their eyes.

Sun and Halpern (40) examined retronasal olfaction using OPCs and cinnamon, anise, mint, coffee, orange, and strawberry as the odorants in their work. A spirometry nose clip was employed to stop orthonasal airflow during the test. Chen and Halpern (41) made further use of the OPC method using non-trigeminal stimulants such as coumarin, octanoic acid, vanilla, octane, and phenyl ethyl alcohol. Studies investigating odorant presentation containers are summarized in Table 3 (39-46). Grenn et al. (45) also used OPC with non-trigeminal stimulants using vanilla, citral, and furaneol.

TABLE 2. Summary of studies investigating candy smell test

\begin{tabular}{|c|c|c|c|c|}
\hline Authors & Aim & Study group & Main finding & Main conclusion \\
\hline Renner et al. ${ }^{37}$ & $\begin{array}{l}\text { To develop and validate an } \\
\text { olfactory test kit suitable for } \\
\text { children and adults based on } \\
\text { retronasal smelling of aromas } \\
\text { combined with a sweet taste }\end{array}$ & $\begin{array}{l}\text { First, } 353 \text { healthy } \\
\text { subjects ( } 230 \text { children } \\
\text { and } 123 \text { adults) were } \\
\text { investigated in three } \\
\text { separate sessions with } \\
\text { the Candy Smell Test } \\
\text { and the validated } \\
\text { "Sniffin' Sticks". Both } \\
\text { tests were then compared } \\
\text { in } 124 \text { patients with } \\
\text { olfactory disorders }\end{array}$ & $\begin{array}{l}\text { Test results correlated significantly with } \\
\text { the "Sniffin' Sticks" score } \mathrm{r}(366)=0.84 \text {, } \\
\mathrm{p}<0.001 \text { ), although the Candy Smell } \\
\text { test proved to be much easier to } \\
\text { administer. The age limit for obtaining } \\
\text { valid data was } 7 \text { years for both tests. } \\
\text { The cutoff limit for the Candy Smell } \\
\text { test scores to separate normosmics from } \\
\text { dysosmics was a score of } 16 \text { or less out } \\
\text { of } 23 \text {. Anosmia (cutoff score }=13 \text { ) was } \\
\text { detected with a sensitivity of } 94 \% \text { and a } \\
\text { specificity of } 83 \%\end{array}$ & $\begin{array}{l}\text { The Candy Smell test is an easy- } \\
\text { to-use, reliable, and fast test of } \\
\text { retronasal olfactory performance } \\
\text { suitable for the screening of smell } \\
\text { function in adults and children } \\
\text { above the age of } 6 \text { years }\end{array}$ \\
\hline Haxel et al. ${ }^{38}$ & $\begin{array}{l}\text { The aim of this study was to } \\
\text { evaluate the Candy Smell Test in } \\
\text { a clinical setting in patients with } \\
\text { olfactory dysfunction and normal } \\
\text { controls against the Sniffin' Sticks } \\
\text { test. Furthermore, cutoff points for } \\
\text { normal and pathological results } \\
\text { in the Candy Smell test should be } \\
\text { determined }\end{array}$ & $\begin{array}{l}\text { The olfactory } \\
\text { performances of } 96 \\
\text { patients presenting with } \\
\text { olfactory disorders and } \\
71 \text { healthy controls was } \\
\text { evaluated }\end{array}$ & $\begin{array}{l}\text { The Candy Smell test correlated well } \\
\text { with the Sniffin' Sticks test for all tested } \\
\text { subjects and for patients }(\mathrm{n}=96) \text { and } \\
\text { controls ( } \mathrm{n}=71) \text {. The proposed cutoff } \\
\text { value to differentiate normosmia from } \\
\text { hyposmia in the Candy Smell test was a } \\
\text { score of }<16 \text { (i.e., } 16 \text { correctly identified } \\
\text { odors) of } 23 \text {. A score below } 13 \text { in the } \\
\text { Candy Smell test was the cutoff value } \\
\text { for anosmia }\end{array}$ & $\begin{array}{l}\text { The Candy Smell test is an } \\
\text { easy-to-handle, reliable tool to } \\
\text { investigate retronasal olfaction } \\
\text { suited for clinical determination } \\
\text { of normosmia, hyposmia, and } \\
\text { anosmia }\end{array}$ \\
\hline
\end{tabular}


TABLE 3. Summary of studies investigating odorant presentation containers

\begin{tabular}{lll}
\hline Authors & Aim & Substances of retronasal olfaction \\
\hline & & \\
& $\begin{array}{l}\text { Subjects were trained to identify } \\
\text { by assigned number common } \\
\text { substances presented as vapor- } \\
\text { phase stimuli via an orthonasal or a } \\
\text { retronasal route }\end{array}$ & $\begin{array}{l}\text { Spice Islands Oregano Powder, } \\
\text { Maxwell House Filterpack ground } \\
\text { coffee, McCormick's Garlic }\end{array}$ \\
$\begin{array}{l}\text { Powder, and either Hershey's } \\
\text { Halpern and }{ }^{39} \\
\text { (experiment One) or Ivory Soap }{ }^{\circledR} \\
\text { (experiments two through four) }\end{array}$
\end{tabular}

To investigate whether exposure to styrene was associated with olfactory impairment, olfactory Dalton et function was examined in workers al. 42 with a minimum of 4 years exposure to styrene in the reinforced-plastics industry and in a group of age- and gendermatched, unexposed controls

The purpose of this study was to

Sun and investigate possible interactions Halpern 40 between ID of air-phase odorants smelled via retronasal and orthonasal routes

To examine retronasal identification of orthonasally

Chen and characterized purely olfactory Halpern ${ }^{41}$ odorants and to compare retronasal and OCO identification of these odorants

Retronasal and oral-cavity-only Dragich and identifications of six natural extract Dragich and odorants, presented in air-phase, were compared in an initial experiment
Peppermint, lemon, coffee, banana, and butterscotch

Study group

Ten men and five women

Workers 52, controls 52

Anise (A), cinnamon (Ci), coffee $(\mathrm{Co})$, orange $(\mathrm{O})$, peppermint $(\mathrm{P})$, and strawberry (S)

Vanillin, octanoic acid, phenylethyl alcohol, coumarin, and octane
Anise, cinnamon, coffee, orange, peppermint, and strawberry
Twenty participants, 9 females and 11 males
Twenty paid volunteers, mean and median age $=20$ years (range: $18-22$ years), 11 females and 9 males

20 paid volunteers, 14 females and 6 males (mean age $=22$ years), ranging from 18 to 49 years of age
Main conclusion

The observed substantial positive transfers between retronasal and orthonasal odorant identification training and testing loci demonstrate that these odorant pathways do not subserve completely independent olfactory systems, while the less accurate identifications via the retronasal route, unless instruction in retronasal breathing was given, suggest a difference in the efficiency with which odorants are normally delivered to the olfactory mucosa

The present study found no evidence among a cross-section of reinforcedplastics industry workers that current or historical exposure to styrene was associated with impairment of olfactory function. Taken together with anatomical differences between rodent and human airways and the lack of evidence for styrene metabolism in human nasal tissue, the results strongly suggest that at these concentrations, styrene is not an olfactory toxicant in humans

The heterogeneous odorant ID outcome supports the concept that processing of retronasal and orthonasal odorants differ, and the perceived reversal of the presented sequence agrees with the importance of recency in odorant memory

Correct retronasal identifications for the studied

non-trigeminal odorants were qualitatively comparable to orthonasal identifications and were both much more frequent and faster than identifications for OCO presentations.

These outcomes suggest that peppermint-like odorants can initiate sufficiently differential responses in the oral cavity to permit identification, indicating that not only odorants with known trigeminal stimulus components but also others may elicit oral-cavityonly air-phase responses and implying that for a substantial minority of individuals, trigeminal input may enhance the oral-cavity effectiveness of many odorants during retronasal smelling

30 paid volunteers, 17

Linoleic, oleic, and stearic fatty acids males and 13 females.

(Age range $=19-60$ years, mean $=26.6$ years $)$
Human participants can discriminate linoleic, oleic, and stearic fatty acids both orthonasally and retronasally, confirming that humans can smell fatty acids 
TABLE 3. Continued

\begin{tabular}{|c|c|c|c|c|}
\hline Authors & Aim & Substances of retronasal olfaction & Study group & Main conclusion \\
\hline $\begin{array}{l}\text { Green } \\
\text { et al. }{ }^{45}\end{array}$ & $\begin{array}{l}\text { The purpose of the present study } \\
\text { was therefore to measure the } \\
\text { potential for enhancement, both } \\
\text { of taste by odors and of odors by } \\
\text { tastes, using a psychophysical } \\
\text { procedure that gave subjects } \\
\text { appropriate response categories } \\
\text { with which to rate the intensities of } \\
\text { both kinds of sensations }\end{array}$ & Vanillin, citral, and furaneol & $\begin{array}{l}31 \text { subjects ( } 18 \text { females } \\
\text { and } 13 \text { males) between } 18 \\
\text { and } 45 \text { years of age }\end{array}$ & $\begin{array}{l}\text { It is proposed that enhancement of } \\
\text { retronasal odors by a sweet stimulus } \\
\text { results from an adaptive sensory } \\
\text { mechanism that serves to increase the } \\
\text { salience of the flavor of nutritive foods }\end{array}$ \\
\hline $\begin{array}{l}\text { Chukir } \\
\text { et al. }{ }^{46}\end{array}$ & $\begin{array}{l}\text { Based on prior psychophysical } \\
\text { reports and the chemistry and } \\
\text { physiology of linoleic, oleic, and } \\
\text { stearic acids, the hypotheses for } \\
\text { linguistic identifications of these } \\
\text { long-chain 18-carbon fatty acids, } \\
\text { together with geraniol and PEA, of } \\
\text { this present study were 1) the } \\
3 \text { fatty acids would receive } \\
\text { identifications that differed from } \\
\text { those for geraniol and PEA; } \\
\text { 2) stearic acid would receive } \\
\text { identifications that differed from } \\
\text { linoleic and oleic acids; and 3) } \\
\text { identifications for linoleic and } \\
\text { oleic acids would not differ from } \\
\text { each other }\end{array}$ & $\begin{array}{l}\text { The long-chain 18-carbon fatty } \\
\text { acids linoleic, oleic, and stearic } \\
\text { acids }\end{array}$ & $\begin{array}{l}36 \text { paid volunteers ( } 24 \\
\text { females, } 12 \text { males), } \\
\text { ranging from } 18 \text { to } 71 \\
\text { years of age, with an } \\
\text { overall median of } 21 \text { years } \\
\text { (semiquartile range= } 2 \\
\text { years) }\end{array}$ & $\begin{array}{l}\text { Retronasal vapor-phase stearic acid } \\
\text { was identified differently from other } \\
18 \text {-carbon fatty acids by a substantial } \\
\text { minority of participants, but linoleic } \\
\text { and oleic acids were not, suggesting } \\
\text { that these } 2 \text { vapor-phase } 18 \text {-carbon fatty } \\
\text { acids can be identified retronasally as a } \\
\text { group but not separately }\end{array}$ \\
\hline
\end{tabular}

\section{DISCUSSION}

\section{Summary of Evidence}

\section{Summary of the retronasal olfaction test}

A consistent finding among studies that focused on ROT was the strict use of the original retronasal olfaction measuring technique introduced by Heilmann et al. (16). Applying the test powder in the mouth while clipping the nose is a standard practice. To assess the validation of this test, many authors utilized the orthonasal olfaction test SST.

In our opinion, the selection of preferred odorant agents should be made with consideration of their societal commonality. Particularly, the test agents used in retronasal olfaction testing should be varied because of the sociocultural variations seen with orthonasal testing. For this purpose, some authors employ a preliminary questionnaire to learn the most familiar and recognizable flavors (22). A Turkish population survey made by Salihoglu et al. (33) in 2014 required a modification of the test powders because of sociocultural mismatch. After a questionnaire about the knowledge of flavors planned for the test was completed by all participants, celery, curry, ginger, ham, and blackberries were exchanged for cumin, sesame, thyme, sausage, and banana, respectively. The conclusion of this study was compatible with the method of Heilmann et al. (16). The author re-used the test in his later study that focused on evaluating retronasal olfaction in obstructive sleep apnea (OSA). No significant decrease was experienced in retronasal olfaction in contrast to ortanasal olfaction. The authors attributed their result to cultural variation (31). Besides, many researchers consistently excluded lemon and pepper due to their trigeminal stimulant characteristics.

Another interesting issue is that nasal mechanical obstruction, $\mathrm{NP}$, and $\mathrm{AH}$ are disorders found to disrupt orthonasal more than retronasal olfaction. However, retronasal olfaction recovers after surgical treatment. Altundag et al. (34) employed the same test to investigate the relationship between $\mathrm{AH}$, tonsil hypertrophy $(\mathrm{TH})$, and retronasal olfaction, indicating that $\mathrm{AH}$ was a negative effector in both orthonasal and retronasal olfaction, but TH was only a factor in retronasal olfaction. Correlation analyses showed that the size and volume of adenoid tissue were stronger determinants of retronasal compared with orthonasal olfaction. On the other hand, pathologies that block the upper airway, such as TL, reduce both orthonasal and retronasal olfactory function. Advancing age is, interestingly, only responsible for a reduction in orthonasal olfaction. Despite its frequent use, the retronasal test is only performed within supra-threshold margins in the literature. Thus, the exact threshold concentrations remain undefined.

\section{Summary of the candy smell test}

The CST, like the ROT, utilizes test ingredients that stimulate both taste and smell simultaneously. Additionally, and similarly to the ROT, the intensity, concentration, and doses of applications are undefined in CST. Both tests ignore the proper thresholds of retronasal olfaction.

\section{Summary of the odorant presentation container test}

The OPC method obtains information about the air phase of retronasal olfaction in the supra-threshold zone in addition to taste function. Mechanical stimulation of the oral-cavity mucosa 
and the unknown concentration of the odorant inside the mouth are the most significant limitations of this technique. Moreover, the contributions of orthonasal olfaction are ignored during this technique.

\section{Limitations}

Our study of the literature consistently revealed two limitations of olfaction testing: a lack of use of known concentrations and doses of the test substances and conducting tests within the suprathreshold zone. Additionally, no particular procedure was described to detect threshold sensation. The absence of such standardizations probably underlies the delay in progress of these tests and prevents them from being employed in routine clinical use.

In conclusion, the appropriate test agents and optimal concentrations for the ROT remain unclear and emerge as limitations of the ROT technique. From our point of view, the first step to overcoming these limitations will probably require identification of retronasal olfaction thresholds. Once these are determined, the concept of retronasal olfaction and its testing methods may be thoroughly reviewed.

Conflict of Interest: No conflict of interest was declared by the authors.

Financial Disclosure: No financial disclosure was declared by the authors.

\section{REFERENCES}

1. Frasnelli J, Hummel T. Olfactory dysfunction and daily life. Eur Arch Otorhinolaryngol. 2005;262:231-5.

2. Santos DV, Reiter ER, DiNardo LJ, Costanzo RM. Hazardous events associated with impaired olfactory function. Arch Otolaryngol Head Neck Surg 2004;130:317-9.

3. Bushdid C, Magnasco MO, Vosshall LB, Keller A. Humans can discriminate more than 1 trillion olfactory stimuli. Science 2014;343:1370-2.

4. Jankowski R. Revisiting human nose anatomy: phylogenic and ontogenic perspectives. Laryngoscope 2011;121:2461-7.

5. Guyton A.C, Hall J.E. T1bbi Fizyoloji, Editor: Cavusoglu H. 11th edt. İstanbul, Nobel Medicine Bookstore, 2007;663-70.

6. Small DM, Gerber JC, Mak YE, Hummel T. Differential neural responses evoked by orthonasal versus retronasal odorant perception in humans. Neuron 2005;47:593-605.

7. Bojanowski V, Hummel T. Retronasal perception of odors. Physiol Behav 2012;107:484-7.

8. Halpern BP. Retronasal and orthnasal smelling. Chemo Sense 2004;6:1-7.

9. Evren C, Yigit VB, Cinar F. Subjective assessment of olfactory function. Kulak Burun Bogaz Ihtis Derg 2015;25:59-64.

10. Hummel T, Sekinger B, Wolf SR, Pauli E, Kobal G. 'Sniffin' sticks': olfactory performance assessed by the combined testing of odor identification, odor discrimination and olfactory threshold. Chem Senses 1997;22:39-52.

11. Doty RL, Shaman P, Kimmelman CP, Dann MS. University of Pennsylvania Smell Identification Test: arapid quantitative olfactory function test for the clinic. Laryngoscope 1984;94:176-8.

12. Cain WS, Gent JF, Goodspeed RB, Leonard G. Evaluation of olfactory dysfunction in the Connecticut Chemosensory Clinical Research Center. Laryngoscope 1988;98:838 .

13. Rombaux P, Weitz H, Mouraux A, Nicolas G, Bertrand B, Duprez T, et al. Olfactory function assessed with orthonasal and retronasal testing, olfactory bulb volume, and chemosensory event-related potentials. Arch Otolaryngol Head Neck Surg 2006;132:1346-51.

14. Tsukatani T, Reiter ER, Miwa T, Costanzo RM. Comparison of diagnostic findings using different olfactory test methods. Laryngoscope 2005;115:1114-7.

15. Higgins JPT, Green S (editors). Cochrane Handbook for Systematic Reviews of Interventions Version 5.1.0 [updated March 2011]. The Cochrane Collaboration, 2011. Available from www.handbook.cochrane.org.
16. Heilmann S, Strehle G, Rosenheim K, Damm M, Hummel T. Clinical assessment of retronasal olfactory function. Arch Otolaryngol Head Neck Surg 2002; 128:414 8.

17. Landis BN, Giger R, Ricchetti A, Leuchter I, Hugentobler M, Hummel T, et al Retronasal olfactory function in nasal polyposis. Laryngoscope 2003;113:1993-7.

18. Konstantinidis I, Triaridis S, Triaridis A, Petropoulos I, Karagiannidis K, Kontzoglou G. How do children with adenoid hypertrophy smell and taste? Clinical assessment of olfactory function pre- and post-adenoidectomy. Int $\mathrm{J}$ Pediatr Otorhinolaryngol 2005;69:1343-9.

19. Pfaar O, Landis BN, Frasnelli J, Hüttenbrink KB, Hummel T. Mechanical obstruction of the olfactory cleft reveals differences between orthonasal and retronasal olfactory functions. Chem Senses 2006;31:27-31.

20. Rombaux P, Weitz H, Mouraux A, Nicolas G, Bertrand B, Duprez T, et al. Olfactory function assessed with orthonasal and retronasal testing, olfactory bulb volume, and chemosensory event-related potentials. Arch Otolaryngol Head Neck Surg 2006; $132: 1346-51$

21. Leon EA, Catalanotto FA, Werning JW. Retronasal and orthonasal olfactory ability after laryngectomy. Arch Otolaryngol Head Neck Surg 2007;133:32-6.

22. Croy I, Hoffmann H, Philpott C, et al. Retronasal testing of olfactory function: an investigation and comparison in seven countries. Eur Arch Otorhinolaryngol 2014;271:1087-95.

23. Landis BN, Frasnelli J, Reden J, Lacroix JS, Hummel T. Differences between orthonasal and retronasal olfactory functions in patients with loss of the sense of smell. Arch Otolaryngol Head Neck Surg 2005;131:977-81.

24. Rombaux P, Weitz H, Mouraux A, Nicolas G, Bertrand B, Duprez T, et al. Olfactory function assessed with orthonasal and retronasal testing, olfactory bulb volume, and chemosensory event-related potentials. Arch Otolaryngol Head Neck Surg 2006;132:1346-51.

25. Rombaux P, Bertrand B, Keller T, Mouraux A. Clinical significance of olfactory eventrelated potentials related to orthonasal and retronasal olfactory testing. Laryngoscope 2007;117:1096-101

26. Rombaux P, Mouraux A, Collet S, Eloy P, Bertrand B. Usefulness and feasibility of psychophysical and electrophysiological olfactory testing in the rhinology clinic. Rhinology 2009; 47:28-35.

27. Landis BN, Cao Van H, Guinand N, Horvath J, Haehner A, Savva E, et al. Retronasal olfactory function in Parkinson's disease. Laryngoscope 2009;119:2280-3.

28. Fleiner F, Dahlslett SB, Schmidt F, Harms L, Goektas O. Olfactory and gustatory function in patients with multiple sclerosis. Am J Rhinol Allergy 2010;24:e93-7.

29. Roudnitzky N, Bult JH, de Wijk RA, Reden J, Schuster B, Hummel T. Investigation of interactions between texture and ortho- and retronasal olfactory stimuli using psychophysical and electrophysiological approaches. Behav Brain Res 2011;216:10915 .

30. Rombaux P, Huart C, Deggouj N, Duprez T, Hummel T. Prognostic value of olfactory bulb volume measurement for recovery in postinfectious and posttraumatic olfactory loss. Otolaryngol Head Neck Surg 2012;147:1136-41.

31. Salihoğlu M, Kendirli MT, Altundağ A, et al. The effect of obstructive sleep apnea on olfactory functions. Laryngoscope 2014;124:2190-4.

32. Cayonu M, Salihoglu M, Altundag A, Tekeli H, Kayabasoglu G. Grade 4 tonsillar hypertrophy associated with decreased retronasal olfactory function: a pilot study. Eur Arch Otorhinolaryngol 2014;271:2311-6.

33. Salihoglu M, Altundag A, Cayonu M, Tekeli H. An investigation of retronasal testing of olfactory function in a Turkish population. Med Sci Monit 2014;20:569-76.

34. Altundag A, Salihoglu M, Cayonu M, Tekeli H. Clinical assessment of olfactory functions in children who underwent adenotonsillectomy during pre- and postoperative period. Int J Pediatr Otorhinolaryngol 2014;78:1138-42.

35. Altundag A, Cayonu M, Kayabasoglu G, Salihoglu M, Tekeli H, Cayonu S, et al. The evaluation of olfactory function in individuals with chronic halitosis. Chem Senses 2015;40:47-51.

36. Reychler G, Colbrant C, Huart C, Le Guellec S, Vecellio L, Liistro G, et al Effect of three-drug delivery modalities on olfactory function in chronic sinusitis. Laryngoscope 2015;125:549-55.

37. Renner B, Mueller CA, Dreier J, Faulhaber S, Rascher W, Kobal G. The candy smell test: a new test for retronasal olfactory performance. Laryngoscope 2009;119:487-95.

38. Haxel BR, Bertz-Duffy S, Faldum, Trellakis S, Stein B, Renner B, et al. The Candy Smell Test in clinical routine. Am J Rhinol Allergy 2011;25:e145-8. 
39. Pierce J, Halpern BP. Orthonasal and retronasal odorant identification based upon vapor phase input from common substances. Chem Senses 1996;21:529-43.

40. Sun BC, Halpern BP. Identification of air phase retronasal and orthonasal odorant pairs. Chem Senses 2005;30:693-706.

41. Chen V, Halpern BP. Retronasal but not oral-cavity-only identification of "purely olfactory" odorants. Chem Senses 2008;33:107-18.

42. Dalton P, Cowart B, Dilks D, Gould M, Lees PS, Stefaniak A, et al. Olfactory function in workers exposed to styrene in the reinforced-plastics industry. Am J Ind Med 2003;44:1-11.
43. Dragich AM, Halpern BP. An oral-cavity component in retronasal smelling of natural extracts. Physiol Behav 2008;93:521-8.

44. Bolton B, Halpern BP. Orthonasal and retronasal but not oral-cavity-only discrimination of vapor-phase fatty acids. Chem Senses 2010;35:229-38.

45. Green BG, Nachtigal D, Hammond S, Lim J. Enhancement of retronasal odors by taste. Chem Senses 2012;37:77-86.

46. Chukir T, Darlington RB, Halpern BP. Shared retronasal identifications of vaporphase 18-carbon fatty acids. Chem Senses 2013;38:343-53. 